\title{
PENGARUH DISIPLIN KERJA, DAN LINGKUNGAN KERJA TERHADAP KOMITMEN ORGANISASI PEGAWAI UNIVERSITAS MALIKUSSALEH DENGAN KEPUASAN KERJA SEBAGAI VARIABEL INTERVENING
}

\author{
Surito, A. Hadi Arifin, Aiyub \\ PPIM Universitas Malikussaleh Lhokseumawe
}

\begin{abstract}
This study aims to examine the effect of work discipline, and the work environment on organizational commitment of Malikussaleh University with job satisfaction as intervening variable. This research is Quantitative research. The instrument of data collection is using questioner. Determination of respondents using Census techniques. Census is a sample determination technique that takes the entire population into samples. The population in this study was 158 employees at the University of Malikussaleh. The sample in this study that can be used amounted to 153 people while others are not in return. Data analysis using SPSS with path analysis and test sobel. The results of data analysis obtained work discipline, and work environment organizational commitment has a positive and significant impact on job satisfaction Malikussaleh University employees. Work discipline, work environment, and organizational commitment have a positive and significant impact on job satisfaction of Malikussaleh University civil servants. job satisfaction does not mediate the influence of work discipline on employee organizational commitment at Malikussaleh University job satisfaction does not mediate the influence of work environment on organizational commitment of employees at Malikussaleh University,
\end{abstract}

Keywords : Work Discipline and Work Environment, Organizational commitment to Job Satisfaction

\section{PENDAHULUAN}

Mengelola sumber daya manusia dalam sebuah organisasi bukan hal yang mudah untuk dilakukan. Pengukuran yang umum untuk melihat seberapa berhasilnya organisasi mengelola sumber daya manusia adalah dengan melihat komitmen dari setiap individu pegawai dan tentu harus ada tolak ukurnya. Manajemen sumber daya manusia dipandang sebagai faktor pendorong yang utama dalam menentukan keberhasilan suatu organisasi.

Memacu kepuasan kerja pegawai harus dilakukan untuk mendorong pencapaian komitmen organisasi yang baik. Hasibuan (2008), kepuasan kerja adalah sikap emosional yang menyenangkan dan mencintai pekerjaannya. Sikap ini akan berdampak pada moral kerja, kedisiplinan, dan prestasi kerja. Kepuasan kerja juga dipengaruhi oleh displin kerja, Hasibuan (2008) mengatakan kepuasan kerja mempengaruhi tingkat kedisplinan pegawai, artinya jika kepuasan diperoleh dari pekerjaan maka kedisiplinan karyawan baik. Sebaliknya jika kepuasan kerja kurang tercapai dari pekerjaannya maka 
kedisiplinan pegawai rendah. Pegawai yang tingkat kepuasannya tinggi maka secara otomatis komitmen di dalam organisasi akan meningkat.

Mengingat akan arti pentingnya peranan sumber daya manusia yang merupakan faktor penentu keberhasilan suatu organisasi, bahkan manusia memberikan kontribusi terbesar atau menjadi ujung tombak bagi keberhasilan organisasi dibandingkan faktor lain seperti modal, bahan baku atau mesin.

Menurut pengamatan penulis komitmen organisasi pegawai di Universitas Malikussaleh juga masih belum memadai seperti; belum terpenuhinya kebutuhan fisik dengan Tunjangan Prestasi Kerja (TPK) yang masih sangat rendah, tidak terpenuhinya keamanan menjadi masalah tersendiri bagi pegawai, ditambah lagi masih belum terpenuhinya kebutuhan sosial, penghargaan diri dan aktualisasi diri di kalangan staff.

\section{TINJAUAN PUSTAKA}

\section{FAKTOR-FAKTOR YANG MEMPENGARUHI DISIPLIN KERJA}

Disiplin kerja merupakan modal utama yang amat menentukan tingkat kinerja pegawai. Sehingga apabila pegawai tidak disiplin dalam melakukan pekerjaannya dapat dipastikan kinerjanya akan menurun. Disiplin yang baik mencerminkan besarnya rasa tanggung jawab seorang pegawai terhadap tugas-tugas yang diberikan kepadanya.

Menurut Bangsawan (2013), ada 4 faktor yang mempengaruhi disiplin kerja pegawai yaitu:
a. Faktor motivasi,
b. Faktor penegakan disiplin,
c. Faktor kepemimpinan,
d. Gaji dan faktor kompensasi.

Menurut Fachri \& Irawan (2012) faktor-faktor yang mempengaruhi disiplin kerja ada 7, yaitu:

1. Tujuan dan kemampuan karyawan,

2. Teladan Pimpinan,

3. Balas Jasa dan Kesejahteraan,

4. Keadilan,

5. Ancaman,

5. Ketegasan, dan

6. Hubungan Kemanusiaan

Sementara menurut Sinodimedjo dalam Sampeliling (2015), faktor yang mempengaruhi disiplin kerja yaitu:

1. Besar kecilnya pemberian kompensasi,

2. Ada tidaknya keteladanan pimpinan dalam perusahaan,

3. Ada tidaknya aturan pasti yang dapat dijadikan pegangan,

4. Keberanian pimpinan dalam mengambil tindakan,

5. Ada tidaknya pengawasan pimpinan, 
6. Ada tidaknya perhatian kepada para karyawan, dan

7. Diciptakan kebiasaan-kebiasaan yang mendukung tegaknya disiplin.

Sedangkan menurut Khanka (2016), ada beberapa faktor yang dapat menciptakan ketidak disiplinan kerja yaitu:

1. Kepemimpinan yang lemah, fleksibel, tidak kompeten dan penuh kecurigaan.

2. Pengawasan yang tidak sempurna karena ketiadaan pengawas yang baik dan berpengetahuan.

3. Praktek kebijakan membagi kekuasaan menghancurkan semangat tim.

4. Kondisi lingkungan kerja yang tidak sehat dan buruk.

5. Diskriminasi berdasarkan kasta, warna kulit, jenis kelamin, keyakinan, bahasa, jabatan dalam praktek seleksi, promosi dan lain-lain.

6. Koordinasi, delegasi wewenang, dan penetapan tanggungjawab yang salah. Sistem komunikasi yang tidak sempurna.

7. Terhambatnya waktu pemberian ganti rugi dari keluhan karyawan.

Berdasarkan uraian dari beberapa pendapat tersebut dapat disimpulkan ada perbedaan faktor yang mempengaruhi disiplin kerja, hal ini dipengaruhi oleh tempat dan individu yang diteliti. Namun secara umum faktor yang mempengaruhi disiplin pegawai adalah peraturan/tata tertib, pengawasan yang melekat dari pimpinan dan juga sanksi yang tegas terhadap pelanggar peraturan.

\section{INDIKATOR-INDIKATOR DISIPLIN KERJA}

Indikator disiplin diperlukan untuk mengukur tingkat kedisiplinan sebuah organisasi. Menurut Alfred (2015), ada 4 indikator disiplin kerja yaitu:

1. Ketepatan waktu

Jika karyawan datang ke kantor tepat waktu, pulang kantor tepat waktu, serta karyawan dapat bersikap tertib maka dapat dikatakan karyawan tersebut memiliki displin kerja yang baik.

2. Pemanfaatan sarana

Karyawan yang berhati-hati dalam menggunakan peralatan kantor untuk menghindari terjadinya kerusakan pada alat kantor merupakan cerminan karyawan yang memiliki disiplin kerja yang baik.

3. Tanggung jawab yang tinggi

Karyawan yang selalu menyelesaikan tugas yang dibebankan kepadanya sesuai dengan prosedur dan bertanggung jawab terhadap hasil kerjanya, dapat pula dikatakan memiliki disiplin kerja yang tinggi.

4. Ketaatan terhadap aturan kantor

Karyawan yang memakai seragam sesuai aturan, mengenakan kartu tanda identitas, ijin apabila tidak masuk kantor, juga merupakan cerminan disiplin yang tinggi. 
Sedangkan menurut Hasibuan (2011), ada 8 indikator disiplin kerja yaitu :

1. Tujuan dan kemampuan, tujuan yang akan dicapai harus jelas dan ditetapkan secara ideal serta cukup menantang bagi kemampuan karyawan.

2. Keteladanan Pimpinan, dalam menentukan disiplin kerja karyawan maka pimpinan dijadikan teladan dan panutan oleh para bawahannya.

3. Balas jasa atau gaji dan kesejahteraan ikut memengaruhi kedisplinan karyawan, karena akan memberikan kepuasan dan kecintaan karyawan terhadap perusahaan/ pekerjaannya.

4. Keadilan, hal ini mendorong terwujudnya kedisiplinan karyawan, karena ego dan sifat manusia yang selalu merasa dirinya penting dan minta diperlakukan sama dengan manusia lainnya.

5. Pengawasan melekat, hal ini harus dijadikan suatu tindakan yang nyata dalam mewujudkan kedisplinan karyawan perusahaan, karena dengan pengawasan ini, berarti atasan harus aktif dan langsung mengawasi perilaku, moral, sikap, gairah kerja, dan prestasi bawahan.

6. Sanksi hukuman, hal ini berperan penting dalam memelihara kedisiplinan karyawan. Karena dengan adanya sanksi hukuman yang semakin berat, karyawan akan semakin takut melanggar peraturan-peraturan perusahaan, sikap dan perilaku yang indisipliner karyawan akan berkurang.

7. Ketegasan, pemimpin harus berani tegas bertindak untuk menghukum setiap karyawan yang indispliner sesuai dengan sanksi hukuman yang telah ditetapkan.

8. Hubungan kemanusiaan, hubungan yang harmonis di antara sesama karyawan ikut menciptakan kedisiplinan yang baik pada suatu perusahaan. Jika tercipta human relationship yang serasi, maka terwujud lingkungan dan suasana kerja yang nyaman. Hal ini akan memotivasi kedisiplinan yang baik pada perusahaan.

Sementara menurut Harlie (2010) intikator-indikator disiplin kerja di antaranya adalah sebagai berikut :

1. Selalu hadir tepat waktu,

2. Selalu mengutamakan presentase kehadiran,

3. Selalu mentaati ketentuan jam kerja,

4. Selalu mengutamakan jam kerja yang efisien dan efektif,

5. Memiliki keterampilan kerja pada bidang tugasnya,

6. Memiliki semangat kerja yang tinggi,

7. Memiliki sikap yang baik, dan

8. Selalu kreatif dan inovatif dalam bekerja.

Menurut Rivai (2016), indikator dari disiplin kerja yaitu:

1. Kehadiran. Hal ini menjadi indicator yang mendasar untuk mengukur kedisiplinan, dan biasanya karyawan yang memiliki disiplin kerja rendah terbiasa untuk terlambat dalam bekerja.

2. Ketaatan pada peraturan kerja. Karyawan yang taat pada peraturan kerja tidak akan melalaikan prosedur kerja dan akan selalu mengikuti pedoman kerja yang ditetapkan oleh perusahaan.

3. Ketaatan pada standard kerja. Hal ini dapat dilihat melalui besarnya tanggungjawab karyawan terhadap tugas yang diamanahkan kepadanya. 
4. Tingkat kewaspadaan tinggi. Karyawan memiliki kewaspadaan tinggi akan selalu berhati-hati, penuh perhitungan dan ketelitian dalam bekerja, serta selalu menggunakan sesuatu secara efektif dan efisien.

5. Bekerja etis. Beberapa karyawan mungkin melakukan tindakan yang tidak sopan ke pelanggan atau terlibat dalam tindakan yang tidak pantas. Hal ini merupakan salah satu bentuk tindakan indisipliner, sehingga bekerja etis sebagai salah satu wujud dari disiplin kerja karyawan.

Berdasarkan uraian di atas dapat disimpulkan indikator disiplin kerja secara umum adalah ketepatan waktu dalam bekerja, tanggung jawab pegawai yang tinggi, ketaatan pegawai pada aturan organisasi yang berlaku dan juga sanksi yang sesuai diberikan kepada pegawai yang melanggar aturan kedisiplinan yang berlaku. Dengan empat indikator tersebut diharapkan pengukuran disiplin kerja pegawai mendapatkan hasil yang optimal.

\section{KERANGKA KONSEPTUAL}

Disiplin kerja adalah sikap, tingkah laku dan perbuatan yang sesuai dengan peraturan organisasi baik tertulis maupun tidak tertulis (Sutrisno, 2009). Disiplin kerja merupakan bagian atau variabel yang sangat penting dalam pengembangan sumber daya manusia. Oleh karena itu, disiplin kerja diperlukan dalam suatu organisasi agar tidak terjadi keteledoran, penyimpangan atau kelalaian yang menyebabkan terjadinya pemborosan dalam melakukan pekerjaan. Disiplin kerja adalah suatu alat yang digunakan para manajer untuk berkomunikasi dengan karyawan agar bersedia mengubah perilaku serta sebagai upaya untuk meningkatkan kesadaran dan kesediaan seseorang mentaati semua peraturan perusahaan dan norma-norma sosial yang berlaku.

Temuan hasil penelitian terdahulu sangat penting untuk mengetahui sekaligus menguji obyektivitas ilmu yang menjadi suatu masalah dalam penelitian. Beberapa hasil penelitian sebelumnya yang memiliki kaitan dengan masalah yang akan diteliti dalam penelitian ini digunakan oleh peneliti sebagai rujukan untuk lebih memahami antar variabel dalam penelitian ini. Adapun penelitian terdahulu sebagai rujukan dalam penelitian ini dapat di sajikan antara lain sebagai berikut:

Penelitian Ahmad (2013) tentang pengaruh kepemimpinan dan lingkungan kerja terhadap komitmen organisasional dan kinerja karyawan PT. Sumber Djantin di Kalimantan Barat, hasil penelitiannya mendapatkan 5 buah hipotesis, yang mana empat hipotesis yang pengaruh antar variabelnya bersifat positif dan signifikan yaitu kepemimpinan terhadap komitmen organisasional, lingkungan kerja terhadap komitmen organisasional, lingkungan kerja terhadap kinerja karyawan dan komitmen organisasional terhadap kinerja karyawan.

Begitu pula menurut penelitian Gerry, (2012) yang meneliti tentang pengaruh lingkungan kerja dan disiplin terhadap komitmen organisasional pada karyawan Media Cahaya Pagi, mengemukakan hasil penelitian bahwa terdapat pengaruh variabel lingkungan kerja dan disiplin secara simultan berpengaruh tinggi terhadap komitmen organisasional. Variabel lingkungan kerja dan disiplin secara simultan memiliki hubungan cukup kuat dan positif terhadap komitmen organisasional.

Penelitian Lenny (2012) tentang pengaruh kepuasan kerja dan disiplin terhadap komitmen organisasi pegawai dinas perindustrian perdagangan pertambangan dan energi kota Padang. Hasil 
penelitian menunjukkan bahwa terdapat pengaruh signifikan antara kepuasan kerja dan disiplin kerja terhadap komitmen organisasi di Dinas Perindagtamben Kota Padang.

Penelitian Elisabeth, (2014) tentang pengaruh kepuasan kerja dan motivasi kerja terhadap komitmen organisasional dan kinerja karyawan di Kantor Palang Merah Timor Leste menyimpulkan bahwa semua variabel baik kepuasan kerja, motivasi kerja, memiliki pengaruh yang positif dan signifikan terhadap komitmen organisasional dan terhadap kinerja. Berkorelasi positif memiliki arti bahwa semakin tinggi kepuasan kerja seorang karyawan dan motivasinya maka akan semakin baik pula komitmennya dan kinerja karyawan tersebut.

Penelitian Novita, (2016) tentang pengaruh kepuasan kerja dan komitmen organisasional terhadap kinerja karyawan (studi pada PT. Telekomunikasi Indonesia, Tbk Witel Jatim Selatan, Malang) menyimpulkan bahwa kepuasan kerja dan komitmen organisasional berpengaruh secara simultan terhadap kinerja karyawan.

Penelitian Mukti, (2014) tentang pengaruh lingkungan kerja terhadap kepuasan kerja karyawan (Studi pada karyawan PT. Telekomunikasi Indonesia Tbk. Kandatel Malang) menghasilkan kesimpulan yaitu lingkungan kerja fisik dan lingkungan kerja non-fisik secara simultan berpengaruh signifikan terhadap kepuasan kerja karyawan, lingkungan kerja fisik berpengaruh secara positif dan signifikan terhadap kepuasan kerja karyawan, lingkungan kerja non-fisik berpengaruh secara positif dan signifikan terhadap kepuasan kerja karyawan.

Hasil Penelitian Angga (2010) tentang pengaruh lingkungan dan kepuasan kerja karyawan terhadap komitmen organisasional (Studi pada PT. Industri Sandang Nusantara (ISN) Unit Patal Lawang Malang) menyimpulkan bahwa dua variabel yaitu lingkungan kerja dan kepuasan kerja berpengaruh signifikan terhadap komitmen organisasional. Sedangkan variabel kepuasan kerja merupakan variabel yang paling dominan mempengaruhi komitmen organisasional pada PT. ISN unit Patal Lawang-Malang.

Berdasarkan hasil penelitian sebelumnya yang dikemukakan di atas, maka kerangka konseptual yang penulis ajukan dalam penelitian ini adalah pengaruh disiplin kerja dan lingkungan kerja terhadap komitmen organisasi pada Universitas Malikussaleh dengan kepuasan kerja sebagai variabel intervening dapat digambarkan sebagai berikut :

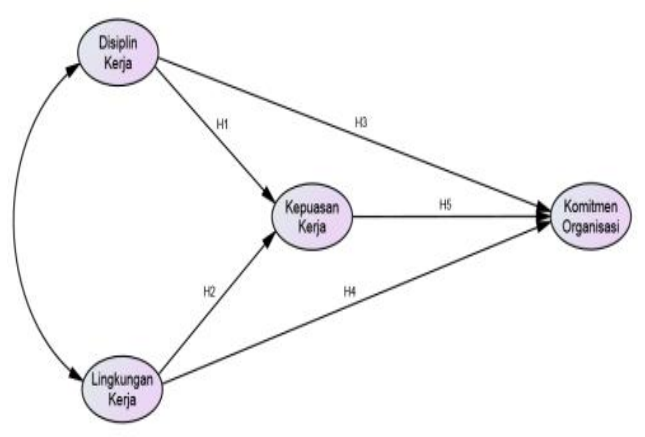

Gambar : Kerangka Konseptual

Sumber: Prihantoro (2012) 


\section{POPULASI DAN SAMPEL}

Menurut Malhortra (2015), keseluruhan dari kumpulan elemen yang memiliki sejumlah karakteristik umum, yang terdiri dari bidang-bidang untuk diteliti. Atau, populasi adalah keseluruhan kelompok dari orang-orang, peristiwa atau barang-barang yang diminati oleh peneliti untuk diteliti. Jadi populasi pada penelitian ini adalah Pegawai Universitas Malikussaleh yang diambil sempelnya berjumlah 158 orang. Adapun komposisi jumlah pegawai Universitas Malikussaleh berdasarkan ruangan dapat di lihat pada Tabel 4.1.

\section{Tabel 4.1}

\section{Jumlah Populasi}

\begin{tabular}{llc}
\hline No & \multicolumn{1}{c}{ Unit Kerja } & Populasi \\
\hline 1 & KPA & 75 \\
2 & LPPM & 7 \\
3 & Fak Ekonomi & 11 \\
4 & Fak Hukum & 8 \\
5 & Fak Teknik & 17 \\
6 & Fak Pertanian & 8 \\
7 & Fak Ilmu sosial \& Ilmu Po. & 13 \\
8 & Fak Kedokteran & 8 \\
9 & F. KIP & 11 \\
\hline & JUMLAH & $\mathbf{1 5 8}$
\end{tabular}

Menurut Malhotra dikutip dalam Amirrulah (2015), sampel merupakan suatu sub kelompok dari populasi yang dipilih untuk digunakan dalam penelitian. Untuk menentukan sampel, penulis mengunakan sampling jenuh (sensus). Sugiyono (2012) mengatakan sampling jenuh (sensus) adalah teknik penentuan sampel bila semua anggota populasi digunakan sebagai sampel. Sampel jenuh juga sering diartikan sampel yang sudah maksimum, ditambah berapapun tidak akan mengubah keterwakilan.

Penelitian ini dilakukan pada Universitas Malikussaleh yang beralamat pada jalan Medan Banda Aceh Cot Teungku Nie - Reuleut Kecamatan Muara Batu - Aceh Utara. Provinsi Aceh. Universitas Malikussaleh didirikan dengan mengambil nama besar Raja Kerajaan Samudera Pasai pertama, yang dilandasi pada semangat estafet kepemimpinan dan pembangunan yang telah diletakkannya melalui sifat kepeloporan, kedinamisan, serta patriotismenya Sultan Malikussaleh.

Sebagai cikal bakal Universitas Malikussaleh bermula dari menjelmanya Akademi Ilmu Agama jurusan Syariah yang didirikan dengan Surat Keputusan Bupati/Kepala Daerah Tingkat II Aceh Utara Nomor : 01/TH/1969 tanggal 12 Juni 1969, pada masa Bupati Drs. Tgk. Abdul Wahab Dahlawy.

Dalam sejarahnya yang panjang dan melalui proses yang rumit pula, akhirnya tanggal 18 Juli 1984 dengan Surat Keputusan Menteri Pendidikan dan Kebudayaan RI Nomor : 0607/0/1984 Sekolah Tinggi Administrasi Negara memperoleh Status Terdaftar. Sedangkan Sekolah Teknik mendapat giliran status terdaftar pada tanggal 24 Agustus 1984, dengan Surat Keputusan Menteri Pendidikan dan Kebudayaan RI Nomor : 0392/0/1984. Selanjutnya pada tahun 1986 didirikan pula Fakultas Pertanian, Fakultas Ekonomi, Fakultas Hukum, serta Fakultas Keguruan dan Ilmu Pendidikan. 


\section{Analisis full Model Sebelum Modifikasi}

Pengujian kesesuaian model SEM sebelum dimodikasi bertujuan untuk melihat sejauh mana model dasar yang dibentuk dalam penelitian ini memenuhi kriteria goodness of fit sehingga model dapat menggambarkan fenomena penelitian tanpa ada modifikasi. Adapun full model SEM sebelum modifikasi dapat dilihat pada Gambar 5.12 di bawah ini :

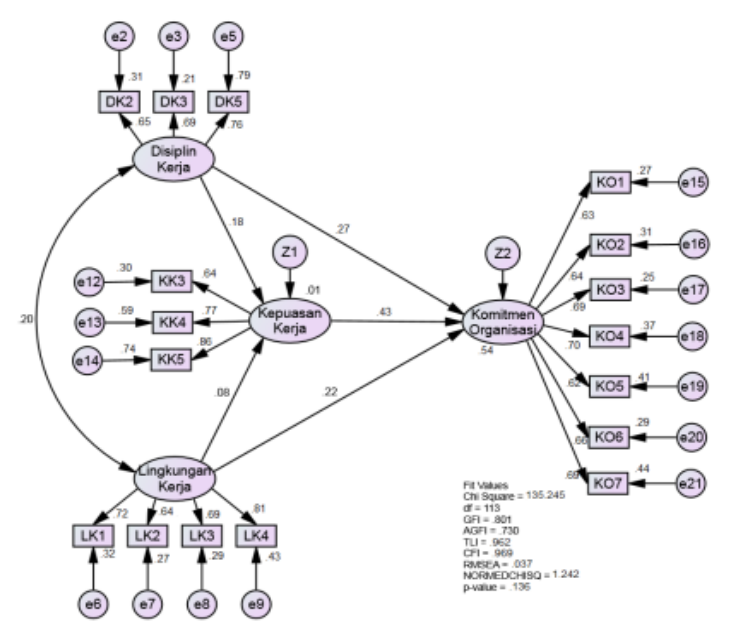

\section{Gambar 5.12 Full model penelitian Sebelum Modifikasi}

Berdasarkan hasil pengolahan data seperti yang diperlihatkan pada Gambar 5.12 di atas, kemudian dimasukan dalam Tabel 5.18 menunjukkan bahwa keseluruahn konstruk yang digunakan untuk membentuk model penelitian ini telah memenuhi kriteria goodness of fit indeks yang telah ditetapkan seperti RMSEA dan CMIN/DF, yang lain seperti probability. GFI, AGFI, TLI dan CFI masih belum memenuhi kriteria yang dipersyaratkan, sehingga dapat disimpulkan model penelitian ini belum fit secara sempurna. Hal ini dapat ditunjukkan seperti pada Tabel 5.18 di bawah ini.

\section{Analisis full Model Setelah Modifikasi}

Pengujian kesesuaian model SEM sebelum dimodikasi bertujuan untuk melihat sejauh mana model dasar yang dibentuk dalam penelitian ini memenuhi kriteria goodness of fit sehingga model dapat menggambarkan fenomena penelitian tanpa ada modifikasi. Adapun full model SEM sebelum modifikasi dapat dilihat pada Gambar 5.13 di bawah ini : 


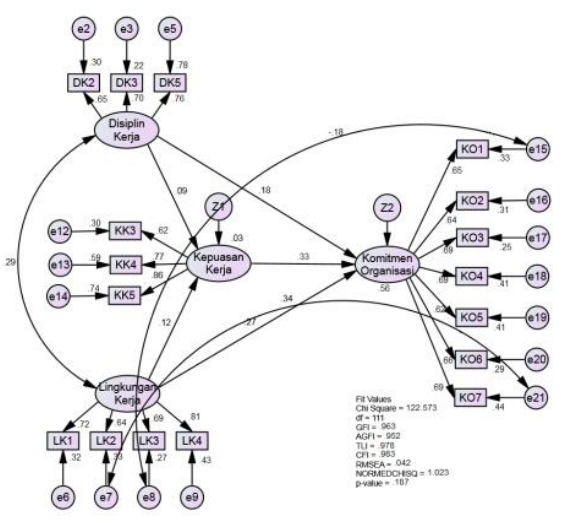

\section{Gambar 5.13 Full model penelitian Setelah Modifikasi}

Berdasarkan hasil pengolahan data seperti yang diperlihatkan pada Gambar 5.13 di atas, kemudian dimasukan dalam tabel 5.20 menunjukkan bahwa keseluruahn konstruk yang digunakan untuk membentuk model penelitian ini telah memenuhi kriteria goodness of fit indeks yang telah ditetapkan seperti RMSEA dan CMIN/DF, yang lain seperti probability. GFI, AGFI, TLI dan CFI masih belum memenuhi kriteria yang dipersyaratkan, sehingga dapat disimpulkan model penelitian ini belum fit secara sempurna.

Berdasarkan angka-angka seperti yang ditunjukkan pada Tabel 5.21 dapat dijelaskan :

1. Nilai koefisien variabel disiplin Kerja terhadap kepuasan kerja adalah sebesar 0,130 dengan nilai signifikan sebesar 0,164 lebih besar dari 0,05 artinya variabel disiplin Kerja berpengaruh positif tetapi tidak signifikan terhadap kepuasan kerja. Dengan demikian, pernyataan Hipotesis pertama disiplin kerja berpengaruh signifikan terhadap kepuasan kerja pegawai. Ditolak.

2. Nilai koefisien variabel lingkungan kerja terhadap kepuasan kerja adalah sebesar 0,121 dengan nilai signifikan sebesar 0,628 lebih besar dari 0,05 artinya variabel lingkungan kerja berpengaruh positif tetapi tidak signifikan terhadap kepuasan kerja. Dengan demikian, pernyataan Hipotesis Kedua Kepuasan Kerja berpengaruh Signifikan terhadap kepuasan kerja pegawai. Ditolak

3. Nilai koefisien variabel disiplin kerja terhadap komitmen organisasi adalah sebesar 0,183 dengan nilai signifikan sebesar 0,008 lebih kecil dari 0,05 artinya variabel disiplin kerja berpengaruh signifikan terhadap komitmen organisasi. Dengan demikian, pernyataan Hipotesis ketiga disiplin kerja berpengaruh signifikan terhadap komitmen organisasi pegawai Universitas Malikussaleh diterima.

4. Nilai koefisien variabel lingkungan kerja terhadap komitmen organisasi adalah sebesar 0,271 dengan nilai signifikan sebesar 0,0001 lebih kecil dari 0,05 artinya variabel lingkungan kerja berpengaruh signifikan terhadap komitmen organisasi. Dengan demikian, pernyataan Hipotesis keempat lingkungan kerja berpengaruh signifikan terhadap komitmen organisasi Pegawai Universitas diterima.

5. Nilai koefisien variabel kepuasan kerja terhadap komitmen organisasi adalah sebesar 0,450 dengan nilai signifikan sebesar 0,0001 lebih kecil dari 0,05 artinya variabel kepuasan kerja 
berpengaruh signifikan terhadap komitmen organisasi. Dengan demikian, pengaruh Hipotesis kelima kepuasan kerja berpengaruh signifikan terhadap komitmen organisasi pegawai Universitas Malikussaleh diterima.

\section{IMPLIKASI SECARA TEORITIS}

Penelitian ini menghasilkan beberapa implikasi secara teoritis yaitu sebagai berikut:

1. Hasil penelitian ini menunjukkan bahwa variabel disiplin kerja berpengaruh positif dan tidak signifikan terhadap kepuasan kerja pegawai pada Universitas Malikussaleh. Hasil ini telah memperkuat dan menambah jumlah literatur ilmiah dalam lingkup teori manajemen sehubungan dengan pengaruh variabel disiplin kerja terhadap kepuasan kerja.

2. Hasil penelitian ini menunjukkan bahwa variabel lingkungan kerja berpengaruh positif dan tidak signifikan terhadap kepuasan kerja kerja pegawai pada Universitas Malikussaleh. Hasil ini telah memperkuat dan menambah jumlah literatur ilmiah dalam lingkup teori manajemen sehubungan dengan pengaruh variabel lingkungan kerja terhadap kepuasan kerja.

3. Hasil penelitian ini menunjukkan bahwa variabel disiplin kerja berpengaruh positif dan signifikan terhadap komitmen organisasi pegawai pada Universitas Malikussaleh. Hasil ini telah memperkuat dan menambah jumlah literatur ilmiah dalam lingkup teori manajemen sehubungan dengan pengaruh variabel disiplin kerja terhadap komitmen organisasi pegawai.

4. Hasil penelitian ini menunjukkan bahwa variabel lingkungan kerja berpengaruh positif dan signifikan terhadap komitmen organisasi pegawai pada Universitas Malikussaleh. Hasil ini telah memperkuat dan menambah jumlah literatur ilmiah dalam lingkup teori manajemen sehubungan dengan pengaruh variabel lingkungan kerja terhadap komitmen organisasi pegawai.

5. Hasil penelitian ini menunjukkan bahwa variabel kepuasan kerja kerja berpengaruh positif dan signifikan terhadap komitmen organisasi pegawai pada Universitas Malikussaleh. Hasil ini telah memperkuat dan menambah jumlah literatur ilmiah dalam lingkup teori manajemen sehubungan dengan pengaruh variabel kepuasan kerja terhadap komitmen organisasi pegawai.

6. Hasil penelitian ini menunjukkan bahwa variabel kepuasan kerja tidak memediasi pengaruh disiplin kerja terhadap komitmen organisasi pegawai pada Universitas Malikussaleh. Hasil ini tidak sesuai dengan hipotesis pada penelitian, perlu dilakukan kajian lebih lanjut tentang faktor-faktor yang dapat memediasi komitmen organisasi. Hasil ini telah memperkuat dan menambah jumlah literatur ilmiah dalam lingkup teori manajemen.

7. Hasil penelitian ini menunjukkan bahwa variabel kepuasan kerja tidak memediasi pengaruh lingkungan kerja terhadap komitmen organisasi pegawai pada Universitas Malikussaleh. Hasil ini tidak sesuai dengan hipotesis pada penelitian, perlu dilakukan kajian lebih lanjut tentang faktorfaktor yang dapat memediasi komitmen organisasi. Hasil ini telah memperkuat dan menambah jumlah literatur ilmiah dalam lingkup teori manajemen. 


\section{IMPLIKASI SECARA PRAKTIS}

Penelitian ini menghasilkan beberapa implikasi secara praktis yaitu sebagai berikut:

1. Dari hasil penelitian ini ditemukan bahwa variabel disiplin kerja berpengaruh positif dan tidak signifikan terhadap kepuasan kerja pegawai pada Universitas Malikussaleh. Ini dikarenakan disiplin kerja pada Universitas Malikussaleh secara umum belum berlangsung baik. Hal ini berimplikasi bahwa variabel disiplin kerja merupakan salah satu variabel prediktor yang perlu diperhatikan para pimpinan pada Universitas Malikussaleh baik kepada pembantu rektor 2, PD 2, kepala biro adm umum dan keuangan, para kabag, KTU, dan kasubbag untuk meningkatkan disiplin kerja.

2. Dari hasil penelitian ini ditemukan bahwa variabel lingkungan kerja berpengaruh positif dan tidak signifikan terhadap kepuasan kerja pegawai pada Universitas Malikussaleh. Ini dikarenakan lingkungan kerja pada Universitas Malikussaleh secara umum belum berlangsung baik. Hal ini berimplikasi bahwa variabel lingkungan kerja merupakan salah satu variabel prediktor yang perlu diperhatikan para pimpinan pada Universitas baik kepada pembantu rektor 2, PD 2, kepala biro adm umum dan keuangan, para kabag, KTU, dan kasubbag untuk meningkatkan meningkatkan motivasi kerja.

3. Dari hasil penelitian ini ditemukan bahwa variabel disiplin kerja berpengaruh positif dan signifikan terhadap komitmen organisasi pegawai Universitas Malikussaleh. Ini dikarenakan kodisi disiplin kerja pada Universitas Malikussaleh baik. Hasil ini menunjukan bahwa karakteristik komitmen organisasi pegawai Unifersitas Malikussaleh sudah baik sehingga perlu dipertahankan.

4. Dari hasil penelitian ini ditemukan bahwa variabel lingkungan kerja berpengaruh negatif dan signifikan terhadap kometmen organisasi pegawai Universitas Malikussaleh, Ini dikarenakan lingkungan kerja pada Universitas Malikussaleh maka berdapak pada peningkatan komitmen organisasi. Hal ini berimplikasi bahwa. Hasil ini menunjukan karakteristik komitmen organisasi pegawai Unifersitas Malikussaleh sudah baik sehingga perlu dipertahankan.

5. Dari hasil penelitian ini ditemukan bahwa variabel kepuasan kerja berpengaruh positif dan signifikan terhadap komitmen organisasi Universitas Malikussaleh. Hasil ini dapat digunakan untuk pengambilan kebijakan atau keputusan agar komitmen organisasi pegawai pada Universitas Malikussaleh dapat menjalankan fisi dan misinya.

6. Dari hasil penelitian ini ditemukan bahwa variabel kepuasan kerja memediasi pengaruh disiplin kerja komitmen organisasi Universitas Malikussaleh ini dikarenakan kepuasan kerja memediasi pengaruh disiplih kerja, komitmen organisasi secara umum masih rendah, dalam hal ini berimplikasi bahwa mediasi komitmen organisasi salah satu variabel yang perlu diperhatikan oleh manajemen Universitas Malikussaleh.

7. Dari hasil penelitian ini ditemukan bahwa variabel kepuasan kerja tidak memediasi pengaruh lingkungan kerja terhadap komitmen organisasi Universitas Malikussaleh, ini dikarenakam mediasi lingkungan kerja terhadap komitmen organisasi secara umum masih rendah, dalam hal ini berimplikasi mediasi lingkungan kerja terhadap komitmen organisasi salah satu variabel yang perlu di perhatikan oleh manajemen Universitas Malikussaleh 


\section{SIMPULAN}

Penelitian ini menghasilkan beberapa implikasi secara teoritis yaitu sebagai berikut:

1. Hasil penelitian ini menunjukkan bahwa variabel disiplin kerja berpengaruh positif dan tidak signifikan terhadap kepuasan kerja pegawai pada Universitas Malikussaleh..

2. Hasil penelitian ini menunjukkan bahwa variabel lingkungan kerja berpengaruh positif dan tidak signifikan terhadap kepuasan kerja kerja pegawai pada Universitas Malikussaleh.

3. Hasil penelitian ini menunjukkan bahwa variabel disiplin kerja berpengaruh positif dan signifikan terhadap komitmen organisasi pegawai pada Universitas Malikussaleh.

4. Hasil penelitian ini menunjukkan bahwa variabel lingkungan kerja berpengaruh positif dan signifikan terhadap komitmen organisasi pegawai pada Universitas Malikussaleh.

5. Hasil penelitian ini menunjukkan bahwa variabel kepuasan kerja kerja berpengaruh positif dan signifikan terhadap komitmen organisasi pegawai pada Universitas Malikussaleh.

6. Hasil penelitian ini menunjukkan bahwa variabel kepuasan kerja tidak memediasi pengaruh disiplin kerja terhadap komitmen organisasi pegawai pada Universitas Malikussaleh.

7. Hasil penelitian ini menunjukkan bahwa variabel kepuasan kerja tidak memediasi pengaruh lingkungan kerja terhadap komitmen organisasi pegawai pada Universitas Malikussaleh.

\section{SARAN}

Berdasarkan hasil temuan penelitian ini seperti yang telah disebutkan pada bagian kesimpulan maka penelitian ini memberikan beberapa saran semoga bermanfaat secara praktis maupun teoritis. Adapun saran-saran dalam penelitian ini adalah sebagai berikut:

1. Bagi Universitas Malikussaleh untuk dapat meningkatkan kinerja PNS dengan memperhatikan disiplin kerja agar meningkatkan kinerja PNS. Hal ini karena dalam penelitian ini ditemukan bahwa disiplin kerja dapat meningkatkan kinerja PNS.

2. Bagi Universitas Malikussaleh untuk dapat meningkatkan kinerja PNS dengan memperhatikan linhkungan kerja agar meningkatkan kinerja PNS. Hal ini karena dalam penelitian ini ditemukan bahwa lingkungan kerja dapat menurunkan kinerja PNS. Pada Universitas Malikussaleh .

3. Bagi Universitas Malikussaleh untuk dapat meningkatkan kinerja PNS dengan memperhatikan komitmen organisasi agar meningkatkan kepuasan kerja dan kinerja PNS. Hal ini karena dalam penelitian ini ditemukan bahwa komitmen organisasi dapat meningkatkan kepuasan kerja dan kinerja PNS. Universitas Malikussaleh.

4. Bagi Universitas Malikussaleh perlu melakukan langkah-langkah antisipasi, untuk meningkatkan kinerja PNS dengan memberikan perhatian, penghargaan seperti promosi, tunjangan, adil, dan kompetitif, mendisiplinkan kerja dan juga menciptakan lingkungan kerja yang nyaman untuk bekerja. Disamping itu juga perlu menyeimbangkan kinerja agar tidak berdampak negatif terhadap kinerja mereka.

5. Bagi penelitian selanjutnya dapat melakukan penelitian sejenis dengan mempertimbangkan variabel-variabel lainnya yang berpengaruh terhadap kinerja PNS seperti variabel komitmen organisasi, kepuasan kerja, dan variabel-variabel lain yang telah terbukti berpengaruh terhadap kinerja pegawai Universitas Malikussaleh. 


\section{KETERBATASAN PENELITIAN}

Penelitian ini memiliki keterbatasan atau kekurangan, diantaranya adalah sebagai berikut:

1. Penelitian ini mengambil lokasi pada Universitas Malikussaleh, sehingga hasil penelitian belum mampu memberikan gambaran hasil secara menyeluruh terhadap organisasi yang ada di Universitas Malikussaleh, terutama yang berhubungan dengan disiplin kerja, dan lingkungan kerja, komitmen organisasi kepuasan kerja sebagai variaber intervening. Oleh karena itu, kepada peneliti selanjutnya agar dapat mengambil keseluruhan pada Universitas Malikussaleh.

2. Model penelitian ini menggunakan analisis jalur (path analysis) dengan SPSS yang sederhana, oleh karena itu disarankan kepada peneliti berikutnya sebaiknya menggunakan model Struktural Equation Modelling (SEM) dalam analisis data.

\section{DAFTAR PUSTAKA}

Abidin, Zainal, Iqbal Muhammad., Pahtuluran, Yonathan., Maria, Siti. (2016). Pengaruh Kepuasan Kerja, Lingkungan Kerja dan Efikasi Diri Terhadap Komitmen Organisasi di Rumah Sakit SMC Samarinda. Jurnal Ekonomi dan Keuangan Volume 13, No.1, 2016.

Adelia, Candra, Rini, A.A Sg., dan Mujiati, Ni Wayan. (2016). Pengaruh Kompensasi, Gaya Kepemimpinan dan Stress Kerja Terhadap Kepuasan Kerja Karyawan di RS Dharma Kerti. EJurnal Manajemen Unud, Vol. 4, No.4, 2016.

Akbar, Amidhan, Alfian. (2015). Pengaruh Kompensasi, Motivasi, Disiplin Kerja Terhadap Kinerja Karyawan CV. Cemara Production Surabaya. Jurnal Ilmu dan Riset Manajemen Volume 4, Nomor 10, Oktober 2015.

Amirullah. (2015). Populasi dan Sampel (Pemahaman, Jenis dan Teknik). Bayumedia Publising, Malang.

Arifin, Miftahul Rifki. (2013). Pengaruh Kepuasan Kerja dan Disiplin Kerja Terhadap Kinerja Karyawan pada PT Tri Keeson Utama Garut. Jurnal Universitas Komputer Indonesia, 2013.

Aruan, Stevani Quinerita., Fakhri, Mahendra. (2015). Pengaruh Lingkungan Kerja Terhadap Kepuasan Kerja Karyawan Lapangan Departemen Grasberg Power Distribution PT. Freeport Indonesia. Jurnal Modus, Vol.27, No 2, 2015.

Bangsawan, Putra, Bagus, I Gst Ngr. (2012). Analisis Faktor-faktor yang Menentukan Disiplin Kerja Karyawan Pada PT. BPR Luhur Damai Tabanan. Jurnal Universitas Udayana (Unud), Bali.

Belo, Elisabeth., Riana, I Gede., Piartrini, Saroyeni Putu. (2014). Pengaruh Kepuasan Kerja dan Motivasi Kerja Terhadap Komitmen Organisasional dan Kinerja Karyawan di Kantor Palang Merah Timor Leste. E-Jurnal Ekonomi dan Bisnis Universitas Udayana 3 Desember 2014. 
Budianto, A. Aji Tri., dan Katini, Amelia. (2015) Pengaruh Lingkungan Kerja Terhadap Kinerja Pegawai pada PT. Perusahaan Gas Negara (Persero) Tbk SBU Distribusi Wilayah I Jakarta. Jurnal Ilmiah Prodi Manajemen Universitas Pamulang, Vol 3, No.1, Oktober 2015.

Can, Afni., dan Yasri. (2013). Pengaruh Motivasi Kerja, Kepuasan Kerja dan Komitmen Organisasi Terhadap Kinerja Karyawan Pada Bank Nagari.

Fachri, Helman., dan Irawan, Peri. (2010). Faktor-faktor yang Mempengaruhi Disiplin Kerja Pegawai di RRI Pontianak. Jurnal Universitas Muhammadiyah Pontianak.

Farizki, Ressa Muchamad., \& Wahyuati, Aniek. (2017). Pengaruh Motivasi Kerja dan Lingkungan Kerja Terhadap Kinerja Karyawan Medis. Jurnal Ilmu dan Riset Manajemen Volume 6, Nomor 5, Mei 2017.

Haedar., Saharuddin., dan H, Herlangga. (2015). Pengaruh Lingkungan Kerja dan Masa Kerja Terhadap Kepuasan Karyawan pada PT. Hadji Kalla Palopo. Jurnal Manajemen Vol.2, No.1, Februari 2015.

Hanafi, Dwilaksono Bayu. (2017). Pengaruh Motivasi dan Lingkungan Kerja Terhadap Kinerja Karyawan dengan Kepuasan Kerja Sebagai Variabel Mediasi Pada PT. BNI Lifeinsurance. Jurnal Pendidikan Ekonomi dan Bisnis (JPEB), Vol. 5, No.1, Maret 2017.

Hasan, Lenny. (2012). Pengaruh Kepuasan Kerja dan Disiplin Terhadap Komitmen Organisasi Pegawai Dinas Perindustrian Perdagangan Pertambangan dan Energi Kota Padang. Jurnal Manajemen dan Kewirausahaan, Volume 3, Nomor 1, Januari 2012.

Hidayat. (2014). Faktor-faktor Komitmen Organisasi serta Pengaruhnya Terhadap Organizational Citizenship Behavior (OCB). Jurnal NeO-Bis, Vol.8, No.1 Juni 2014.

Lasmaya, Mia S. (2016). Pengaruh Sistem Informasi SDM, Kompetensi dan Disiplin Kerja Terhadap Kinerja Karyawan. Jurnal Ekonomi, Bisnis \& Entrepreneurship Vol 10, No. 1, April 2016.

Leli, R Inong., dan Wardi, Yunia. (2012). Pengaruh Kepuasan Kerja, Motivasi Kerja dan Disiplin Kerja Terhadap Produktivitas Karyawan Instalasi Laboratorium Rumah Sakit Pemerintah di Kota Bukittingi. Jurnal Universitas Negeri Padang.

Liana, Yuyuk., dana Irawati, Rina. (2014). Peran Motivasi, Disiplin Kerja Terhadap Komitmen Karyawan dan Kinerja Karyawan pada Perusahaan Air Minum di Malang Raya. Jurnal Manajemen dan Akuntansi, Volume 3, Nomor, 1, April 2014.

Melani, Titis., dan Suhaji. (2012). Faktor-faktor yang Mempengaruhi Kepuasan Kerja (Studi pada Karyawan Sekolah Tinggi Ilmu Farmasi "Yayasan Pharmasi” Semarang). Jurnal Sekolah Tinggi Ilmu Ekonomi Widya Manggala, Semarang, 2012. 
Mardiono, Dian., dan Supriyatin. (2014). Pengaruh Motivasi dan Disiplin Kerja Terhadap Kepuasan Kerja Karyawan. Jurnal Ilmu \& Riset Manajemen Vol. 3 No. 3, 2014.

Muayanah, Siti., Haryono, Tri Andi., dan Wulan, Sri Heru. (2017). Pengaruh Kompensasi, Lingkungan Kerja, dan Komitmen Organisasi Terhadap Organizational Citizenship Behavior dengan Kepuasan Kerja Sebagai Variabel Intervening (Studi Kasus Pada Karyawan PT. Fajar Lestari Sejati Semarang).

Norianggono, Prasidya Chresstela Yacinda., Hamid Djamhur., dan Ruhana, Ika. (2014). Pengaruh Lingkungan Kerja Fisik dan Non Fisik Terhadap Kinerja Karyawan (Studi pada Karyawan PT. Telkomsel Area III Jawa-Bali Nusra di Surabaya). Jurnal Administrasi Bisnis (JAB) Vol. 8. No. 2. Maret 2014.

Novita., Sunuharjo, Swasto Bambang., dan Ruhana, Ika. (2016). Pengaruh Kepuasan Kerja Dan Komitmen Organisasional Terhadap Kinerja Karyawan. Jurnal Administrasi Bisnis (JAB) Vol.34, No.1, Mei 2016.

Nugroho, Budi Handoko Sri., Choerudin, Achmad., dan Winarna. (2015). Pengaruh Budaya Kerja dan Lingkungan Kerja terhadap Kinerja melalui Motivasi dan Komitmen Organisasi (Studi di Komisi Pemilihan Umum Kabupaten Karanganyar) 2015.

Nurlaely, M., dan Riani, Laksmi. (2016). Pengaruh Disiplin Kerja, Motivasi Kerja, Kepuasan Kerja dan Kompetensi Terhadap Komitmen Organisasi. Jurnal Ekonomi Manajemen Sumber Daya, Vol. 18, No.1, Juni 2016.

Pangarso, Astadi., dan Susanti, I, Putri. (2016). Pengaruh Disiplin Kerja Terhadap Kinerja Pegawai Di Biro Pelayanan Sosial Dasar Sekretariat Daerah Provinsi Jawa Barat. Jurnal Manajemen Teori dan Terapan Tahun 9. No.2, Agustus 2016.

Parwita, Surya Bayu Gde., Supartha, Gede Wayan I., dan Saroyeni, Putu. (2013). Pengaruh Kepuasan Kerja Terhadap Komitmen Organisasi dan Disiplin Kerja. Jurnal Ekonomi dan Bisnis Universitas Udayana (UNUD), Bali.

Permatasari, Ayu, Jundah., Musadieq, Al Mochammad., dan Mayowan, Yuniadi. (2015). Pengaruh

Disiplin Kerja Dan Motivasi Kerja Terhadap Prestasi Kerja Karyawan. Jurnal Administrasi Bisnis (JAB) Vol. 25 No. 1 Agustus 2015.

Prihantoro, Agung. (2012). Peningkatan Kinerja Sumber Daya Manusia Melalui Motivasi, Disiplin, Lingkungan Kerja, Dan Komitmen. Jurnal Unimus, Vol.8, No.2, Maret 2012.

Puspitawati, Dwi Made Ni., Riana, Gede I. (2014). Pengaruh Kepuasan Kerja Terhadap Komitmen Organisasional dan Kualitas Layanan. Jurnal Manajemen Strategi Bisnis dan Kewirausahaan Vol.8, No.1, Februari 2014. 
Puspitasari, Fitria., dan Santoso, Budi Suryono. (2013). Analisis Pengaruh Kualitas Layanan Inti Dan Kualitas Layanan Peripheral Terhadap Kepuasan Nasabah (Studi Pada PT. Bank Negara Indonesia (Persero) Tbk. Cabang Undip Semarang. Jurnal Studi Manajemen \& Organisasi, Vol.10, No.2, Juli 2013.

Riyadi, Mukhlis., dan Indartono, Setyabudi. (2015). Pengaruh Motivasi Kerja Dan Disiplin Kerja Terhadap Kinerja Karyawan Perusahaan Daerah Percetakan Karesidenan Banyumas. Junrla Universitas Negeri Yogyakarta.

Salahuddin, Ahmad. (2013). Pengaruh Kepemimpinan Dan Lingkungan Kerja Terhadap Komitmen Organisasional Dan Kinerja Karyawan PT. Sumber Djantin Di Kalimantan Barat. Jurnal Manajemen Teori dan Terapan, April 2013.

Sampeliling, Alexander. (2015). Faktor-Faktor Yang Berpengaruh Terhadap Kedisiplinan Kerja Pegawai Bagian Umum Dan Protokol Sekretariat Daerah Kabupaten Kutai Timur. Jurnal Kinerja Vol 12 No.1. 2015.

Santoso, Hendrik Michael. (2014). Pengaruh Gaya Kepemimpinan Terhadap Komitmen Organisasional Dengan Kepuasan Kerja Sebagai Variabel Intervening Pada PT Mitra Cimalati Di Cilacap. Jurnal Agora Vol. 2, No.1, 2014.

Saputra, Primananda Angga. (2014). Pengaruh Lingkungan dan Kepuasan Kerja Karyawan Terhadap Komitmen Organisasional (Studi Pada PT. Industri Sandang Nusantara (ISN) Unit Patal Lawang Malang). Jurnal Fakultas Ekonomi dan Bisnis Universitas Brawijaya, Malang.

Sari, Kartika Diah Ni Wayan., dan Dwiranda, A.A.N.B. (2016). Kepuasan Kerja Sebagai Pemediasi Pengaruh Tindakan Supervisi dan Komitmen Organisasi Pada Kinerja Auditor. E-Jurnal Akuntansi Universitas Udayana, Vol.15, No 2, Mei 2016.

Sari, Maya Dwi. (2016). Analisis Pengaruh Lingkungan Kerja Terhadap Kinerja Karyawan Melalui Kepuasan Kerja Sebagai Variabel Intervening (Studi Kasus Pada Bank Tabungan Negara (BTN) Syariah). Skripsi Institut Agama Islam Negeri (IAIN) Salatiga, 2016.

Setiawan, Agung. (2013). Pengaruh Disiplin Kerja Dan Motivasi Terhadap Kinerja Karyawan Pada Rumah Sakit Umum Daerah Kanjuruhan Malang. Jurnal Ilmu Manajemen, Volume 1 Nomor 4 Juli 2013.

Shalahuddin, Ahmad. (2013). Pengaruh Kepemimpinan dan Lingkungan Kerja Terhadap Komitmen Organisasional Dan Kinerja Karyawan PT. Sumber Djantin Di Kalimantan Barat. Jurnal Manajemen Teori dan Terapan Tahun 6, No.1, April 2013.

Sijabat, Jadongan. (2011). Pengaruh Kepuasan Kerja Terhadap Komitmen Organisasi dan Keinginan Untuk Pindah. Jurna Visi, Vol.19, No3, Oktober 2011. 
Sofyan, Khariani Diana. (2013). Pengaruh Lingkungan Kerja Terhadap Kinerja Kerja Pegawai BAPPEDA. Malikussaleh Industrial Engineering Journal Vol. 2, No. 1, 2013.

Sugiyono. (2007). Statistika Untuk Penelitian. Penerbit Alfabeta, Bandung.

Supatmi, Eko, Mamik., Nimran, Umar., dan Utami, Nayati, Hamidah. (2011). Pengaruh Pelatihan, Kompensasi Terhadap Kepuasan Kerja Karyawan Dan Kinerja Karyawan. Jurnal Profit Volume 7 No 1.

Suwondo, Indriani Diah., dan Sutanto, Madiono Eddy. (2015). Hubungan Lingkungan Kerja, Disiplin Kerja, Dan Kinerja Karyawan. Jurnal Manajemen Dan Kewirausahaan, Vol 17, No 2. September 2015.

Wibowo, Mukti., Al Musadieq, Mochammad., dan Nurtjahjono, Gunawan Eko. (2014). Pengaruh Lingkungan Kerja Terhadap Kepuasan Kerja Karyawan (Studi Pada Karyawan PT. Telekomunikasi Indonesia Tbk. Kandatel Malang). Jurnal Administrasi Bisnis. Vol. 16. No. 1, November 2014.

Wowor, J Jr Gerry., Sumayku, M.Sontje., dan Siwi, O.M. (2012). Pengaruh Lingkungan Kerja dan Disiplin Terhadap Komitmen Organisasional Pada Karyawan Media Cahaya Pagi. 2012.

Wuysang, E.B. Pricilya., dan Tawas, N Hendra. (2016). Pengaruh Disiplin Kerja, Perilaku Kepemimpinana dan Motivasi Kerja Terhadap Kepuasan Kerja dan Prestasi Kerja Karyawan KFC Bahu Mall Manado. Jurnal Berkala Ilmiah Efisiensi, Volume 16. No.1, Tahun 2016.

Yulianto. (2011). Hubungan Kesejahteraan, Disiplin Kerja, Lingkungan Kerja dan Kepuasan Kerja Dengan Kinerja Guru Sekolah Menengah Kejuruan Negeri 2 Kabupaten Sragen. Tesis Universitas Sebelas Maret, Surakarta.

Yunus, Alamsyah., dan Bachri, Alim Ahmad. (2013). Pengaruh Disiplin Kerja, Motivasi, Kepemimpinan Terhadap Kepuasan Kerja Karyawan Studi Pada PT. Bumi Barito Utama Cabang Banjarmasin. Jurnal Wawasan Manajemen, Vol 1, Nomor 2, Juni 2013. 